\title{
Urban Termites of Recife, Northeast Brazil (Isoptera)
}

by

\author{
Auristela C. Albuquerque ${ }^{1,3}$, Gicela R. R. S. Matias ${ }^{1}$, Alane A. V. O. Couto ${ }^{1}$, \\ Marco A. P. Oliveira ${ }^{1} \&$ Alexandre Vasconcellos ${ }^{2}$
}

\section{ABSTRACT}

This study surveyed the termite fauna in urban properties of the city of Recife, state of Pernambuco, northeastern Brazil. Six-hundred properties were inspected in search for termites or signs of their activity, such as abandoned nests, galleries on walls, and fecal pellets. Seven termite species, belonging to seven genera and three families (Kalotermitidae, Rhinotermitidae, and Termtidae) were found causing some type of damage. Nasutitermes corniger and Cryptotermes dudleyi were the most frequent species within buildings (82.4\% and $9.5 \%$, respectively). Such species, along with Coptotermes gestroi, were responsible for the greatest damage recorded. With the exception of Cryptotermes dudleyi and Coptotermes gestroi, all of the species are native and relatively common in northeastern Brazil's Atlantic forest.

Keywords: Isoptera, urban entomology, pest status

\section{INTRODUCTION}

Termites are mainly distributed throughout tropical and subtropical regions. In South America there are approximately 400 termite species, of which 77 have already been recorded in environments altered by human activity; however, only about $5 \%$ of the South American species have real pest potential in agricultural or urban areas (Constantino 2002).

The urbanization process has caused a gradual substitution of natural habitats for urban spaces. This causes the local eradication of several termite species and favors the selection or installation of synanthropic species that may become pests (Milano 1998, Milano \& Fontes 2002, Vasconcellos \& Bandeira 2006).

\footnotetext{
${ }^{1}$ Departament of Biology, Federal Rural University of Pernambuco, Recife, Brazil.

${ }^{2}$ Departament of Botany, Ecology and Zoology, Bioscience Center, Federal University of Rio Grande do Norte, Natal, Brazil.

${ }^{3}$ Corresponding author: auritermes@yahoo.com.br
} 
Termite infestations in urban areas have already been reported in several South American countries (e.g. Mill 1991; Aber \& Fontes 1993, Fontes 1995, Torales et al. 1997, Bandeira 1998, Constantino \& Dianese 2001, Costa et al. 2009). In the northeastern region, eleven termite species have been recorded causing some type damage specifically within buildings (Bandeira et al. 1998, Vasconcellos et al. 2002). Little is known about urban termites of the city of Recife. Serpa (1993) has listed three termite genera (Coptotermes, Cryptotermes, and Nasutitermes), without citing the species, causing damage to buildings in several points of the city. Milano \& Fontes (2002) have reported the occurrence of Coptotermes gestroi (Wasman) damaging the woodwork of Recife's warehouses.

This study aimed to survey the fauna of urban termites of the city of Recife (Pernambuco, Brazil) and to report the factors that favor these insects' occurrence, their habits, and the damage they cause.

\section{MATERIALS AND METHODS}

Located on the northeastern Brazilian coast, the city of Recife ( $8^{\circ} 04^{\prime} 03^{\prime \prime}$ $\left.\mathrm{S}, 34^{\circ} 55^{\prime} 00^{\prime \prime} \mathrm{W}\right)$ is $219,493 \mathrm{~km}^{2}$ and has a population of approximately 1.422.905 inhabitants. Its climate is hot and humid and the average temperature is of $25.2^{\circ} \mathrm{C}$ (Prefeitura da Cidade do Recife 2011).

This study was carried out between August 2006 and June 2008, in six neighborhoods of Recife: Ibura, Casa Amarela, Várzea, Água fria, Afogados, and Dois Irmãos. Twenty streets were chosen randomly from each neighborhood and five homes were chosen from each street, totalizing 600 sampled homes.

Inspections were carried out in each home, where we examined both the external area (trees, debris, fences, walls, and other structures that could serve as shelter to termites) and the internal area (furniture, wood from the roof, doors, steps, and cracks). Specimens located were collected and later stored in labeled plastic containers along with pieces of nests or tracks to facilitate identification. The material collected was then identified and conserved in $80 \%$ alcohol. Samples are deposited in the Entomological Collection of the Biology Department of the Federal Rural University of Pernambuco and in the Isoptera Collection of the Bioscience Center of the Federal University of Rio Grande do Norte. 


\section{RESULTS AND DISCUSSION}

Seven termite species belonging to seven genera and three families ( $\mathrm{Ka}$ lotermitidae, Rhinotermitidae, and Termitidae) were found causing some kind of damage to Recife's urban environment (Table 1). With the exception of Cryptotermes dudleyi Banks and Coptotermes gestroi, all of the species are native and relatively common to the Atlantic forest of northeastern Brazil (Vasconcellos 2010).

Table 1. Termite species of the urban environment of Recife, NE Brazil.

\begin{tabular}{lll}
\hline \hline Family/Species & Occurrence of each species (\%) & Pest status* \\
\hline Kalotermitidae & * & \\
Cryptotermes dudleyi & 9.46 & ++ \\
Rhinotermidiae & & ++ \\
Coptotermes gestroi & 2.25 & + \\
Heterotermes longiceps & 1.80 & ++ \\
Termitidae & & + \\
Nasutitermes corniger & 82.40 & + \\
Neocapritermes opacus & 0.45 & + \\
Amitermes amifer & 3.15 & \\
Microcerotermes sp. & 0.45 & \\
* + minor; ++ intermediate; +++ major status. & \\
** Cryptotermes brevis has been recorded in Recife's urban environment, but was \\
not collected in this study.
\end{tabular}

Nasutitermes corniger Motschulsky was the most frequent species (82.4\%) among the properties visited and was responsible for the greatest damage to the city of Recife. This species was found in trees, furniture, and walls, but predominantly infecting the woodwork of roofs.

A study carried out by Bandeira(1998) indicated species of the Nasutitermes genus (especially $N$. corniger) as responsible for over $50 \%$ of the damage caused by termites to the city of Belém, northern Brazil. Vasconcellos et al. (2002) listed $N$. corniger as the most frequent species within properties of João Pessoa, Northeast Brazil; there it was responsible for $43 \%$ of the damage caused by termites in that city. There are also records of great damage caused by $N$. corniger in the city of Corrientes, Argentina (Torales 2002). According to Bandeira et al. (1998), the predominance of the Nasutitermes genus in several cities of the Brazilian northern and northeastern regions may be related to 
these species' low selectivity to the type of wood eaten, as they may attach dry or humid wood, hard or soft, wrought or not. Additionally, the construction of compound nests is an important characteristic of N. corniger biology, which increases the complexity of the control measures needed to deal with this species in urban environments (Vasconcellos \& Bandeira 2006).

Cryptotermes dudleyi was the second most frequent species $(9.46 \%)$ and was found mainly attacking furniture. Indicated by Bandeira (1998) as a pest in the city of Belém, $C$. dudleyi has also been observed by Vasconcellos et al. (2002) causing damage to buildings of João Pessoa.

Although it was not collected from the buildings visited, there are samples of Cryptotermes brevis (Walker) deposited in the Isoptera Collection of the Federal University of Rio Grande do Norte that come from Recife. Cryptotermes brevis, along with $N$. corniger, has been considered a serious urban pest in the city of João Pessoa, where it was found in $61 \%$ of the properties analyzed (Vasconcellos et al. 2002). The great success of $C$. brevis as a pest is possibly due to new colonies' rapid adaptation to the large variety of urban conditions and to their high response level to orphanhood (McMahan 1962, Edwards \& Mill 1986).

The species Coptotermes gestroi, Heterotermeslongiceps (Snyder), and Amitermes amifer Silvestri were found in only two of the six neighborhoods visited. Coptotermes gestroi has been indicated by Fontes (1998) and Laera (1998) as one of the species responsible for the greatest damage to urban trees in the cities of São Paulo and Rio de Janeiro, southeastern Brazil. According to the same authors, this is a serious issue as these trees may spread their infestation to buildings and worsen the problem. Fontes \& Milano (2002) have already reported this same species consuming wood in warehouses of Recife.

Heterotermes longiceps and Amitermes amifer were found infesting fences and eating decomposing wood in yards. Heterotemes longiceps has also been found in the urban environments of the cities of Brasília by Constantino \& Dianese (2001), Corrientes by Torales (2002), Belo Horizonte by Milano \& Fontes (2002), João Pessoa by Vasconcellos et al. (2002), and Goiânia by Costa et al. (2009). Amitermes amifer, in turn, has also been found in João Pessoa causing superficial damage to wood objects in gardens (Vasconcelos et al.2002). The remaining species collected in this study occurred less frequently and apparently cause insignificant losses to Recife's properties. 
The occurrence frequency and the intensity of the damage caused to the properties analyzed suggest that only $N$. corniger, $C$. dudley, and C. gestroi can be treated as pests in Recife. The remaining species were found causing little damage to fences and other cellulose objects in gardens and can not be considered as true pests in the city.

\section{REFERENCES}

Aber, A. \& L.R. Fontes 1993. Reticulitermes lucifugus (Isoptera, Rhinotermitidae), a pest of wooden structures, is introduced into the South American Continent. Sociobiology $21(3): 335-339$.

Bandeira, A. G., C. S. Miranda \& A. Vasconcellos 1998. Danos causados por cupins em João Pessoa. Pp. 75-85, In: Fontes, L. R. \& E. Berti-Filho (eds), Cupins: o desafio do conhecimento. Piracicaba: FEALQ.

Bandeira, A. G. Danos causados por cupins na Amazônia brasileira. 1998. Pp. 87-98, In: Fontes,L. R. \& E. Berti-Filho (eds), Cupins: o desafio do conhecimento. Piracicaba: FEALQ.

Constantino, R. 1999. Chave ilustrada para identificação dos gêneros de cupins (Insecta: Isoptera) que ocorrem no Brasil. Papéis Avulsos de Zoologia 40(25): 387-448.

Constantino, R. 2002. The pest termites of South America: taxonomy, distribution and status. Journal of Applied Entomology. 126(7/8): 355-365.

Constantino, R.\&E.C.Dianese 2001. The urban termitefauna ofBrasília, Brazil. Sociobiology. 38: 323-326.

Costa, D. A; K. E. Santo-Filho \& D. Brandão 2009. Padrão de distribuição de cupins na região urbana de Goiânia. Iheringia, Sér. Zoológica. 99(4): 364-367.

Costa-Leonardo, A. M. 2000. Cupins Urbanos: Conhecer para combater. Ciência Hoje.18(165): 74-77.

Edwards, R \& A. E. Mill 1986. Termites in buildings: their biology and control, East Grimstead, Rentokil Limited, 261p.

Fontes, L. R. 1998. Considerações sobre a complexidade da interação entre o cupim subterrâneo, Coptotermes havilandi, e a arborização no meio urbano. Pp. 109-124, In: Fontes, L. R. \& E. Berti-Filho (eds), Cupins: o desafio do conhecimento. Piracicaba: FEALQ.

Fontes, L.R. \& S. Milano 2002. Térmites as na Urban Problem in South América. Sociobiology. 40(1): 107-147.

Laera, L. H. N. 1998. Cupins na arborização urbana do Rio de Janeiro, Brasil. Pp: 125-132, In: Fontes, L. R. \& E. Berti-Filho (eds), Cupins: o desafio do conhecimento. Piracicaba: FEALQ.

McMahan, E. 1962. Laboratory studies of colony establishment and development in Cryptotermes brevis (Walker) (Isoptera: Kalotermitidae). Proceedings of the Hawaiian Entomological Society 18 (1):145-153. 
Milano, S. \& L. R. Fontes 2002. Cupim e cidade: Implicações ecológicas e controle. São Paulo, Brasil. 142p.

Milano, S. 1998. Diagnóstico e controle de cupins em áreas urbanas. Pp. 45-74, In: Fontes, L.R \& E.Berti-Filho (eds), Cupins: o desafio do conhecimento. Piracicaba: FEALQ.

Mill, A. 1991. Termites as structural pests in Amazonia, Brazil.Sociobiology19 (2):339349.

Prefeitura da cidade de Recife. 2011. A cidade do Recife. http://www.recife.pe.gov.br/pr/ secplanejamento/inforec.

Serpa, F. G. 1993. Considerações sobre "cupins" na cidade de Recife. Boletim da Associação Brasileira de Preservadores de Madeira, 75: 1-7.

Torales, G. J., E.R. Laffont, M.O. Arbino \& M.C. Godoy 1997. Primeira lista faunística de los Isopteros de la Argentina. Revista de la Sociedade Entomologica Argentina 56 $(1-4): 47-53$.

Vasconcellos, A.2010. Biomass and abundance of termites in three remnant areas of Atlantic Forest in northeastern Brazil. Revista Brasileira de Entomologia, 54(3): 455-461.

Vasconcellos, A., A. G. Bandeira, C. S. Miranda \& M. P. Silva 2002. Termites (Isoptera) pests in buildings in JoãoPessoa, Brazil. Sociobiology 40(3): 639 - 644.

Vasconcellos, A. \& A. G. Bandeira 2006. Populational and Reproductive Status of a Polycalic Colony of Nasutitermes corniger (Isoptera, Termitidae) in the Urban Area of João Pessoa, NE Brazil. Sociobiology 47(1): 165 - 174.

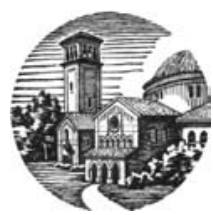

